\title{
An integrated perspective on diabetic, alcoholic, and drug-induced neuropathy, etiology, and treatment in the US
}

This article was published in the following Dove Press journal: Journal of Pain Research

20 January 2017

Number of times this article has been viewed

\author{
Lily Zeng' \\ Doungkamol \\ Alongkronrusmee ${ }^{2}$ \\ Richard M van Rijn ${ }^{2}$ \\ 'Department of Internal Medicine, \\ Vanderbilt University Medical Center, \\ Nashville, TN, ${ }^{2}$ Department of \\ Medicinal Chemistry and Molecular \\ Pharmacology, Purdue University, \\ West Lafayette, IN, USA
}

\begin{abstract}
Neuropathic pain (NeuP) is a syndrome that results from damaged nerves and/or aberrant regeneration. Common etiologies of neuropathy include chronic illnesses and medication use. Chronic disorders, such as diabetes and alcoholism, can cause neuronal injury and consequently NeuP. Certain medications with antineoplastic effects also carry an exquisitely high risk for neuropathy. These culprits are a few of many that are fueling the NeuP epidemic, which currently affects $7 \%-10 \%$ of the population. It has been estimated that approximately $10 \%$ and $7 \%$ of US adults carry a diagnosis of diabetes and alcohol disorder, respectively. Despite its pervasiveness, many physicians are unfamiliar with adequate treatment of NeuP, partly due to the few reviews that are available that have integrated basic science and clinical practice. In light of the recent Centers for Disease Control and Prevention guidelines that advise against the routine use of $\mu$-opioid receptor-selective opioids for chronic pain management, such a review is timely. Here, we provide a succinct overview of the etiology and treatment options of diabetic and alcohol- and drug-induced neuropathy, three different and prevalent neuropathies fusing the combined clinical and preclinical pharmacological expertise in NeuP of the authors. We discuss the anatomy of pain and pain transmission, with special attention to key ion channels, receptors, and neurotransmitters. An understanding of pain neurophysiology will lead to a better understanding of the rationale for the effectiveness of current treatment options, and may lead to better diagnostic tools to help distinguish types of neuropathy. We close with a discussion of ongoing research efforts to develop additional treatments for NeuP.
\end{abstract}

Keywords: small-fiber neuropathy, pain, alcohol use disorder, diabetes mellitus, chemotherapy, opioid receptors

\section{Introduction}

Neuropathic pain (NeuP) arises from aberrant or incomplete regeneration of damaged nerves, and is characterized by hyperalgesia and allodynia, enhanced sensitivity to pain, and exaggerated pain response to normal stimuli. ${ }^{1}$ The prevalence of NeuP varies around the world, but has been cited as at a minimum of $3 \%,{ }^{2-4}$ and true prevalence has been estimated to be around 7\%-10\%. The incidence of NeuP also varies by type, as categorized by the mechanism of injury: diabetic neuropathy, alcoholic neuropathy, and medication-induced neuropathy. ${ }^{6}$ A concerning trend in the US is the rise in diagnosis of neuropathies caused by type 2 diabetes. $^{7}$ This may in part be fueled by increased health care costs hampering proper management of diabetes (diabetes.org). ${ }^{8}$ Alcoholic neuropathy in the US occurs in roughly $65 \%$ of patients diagnosed with an alcohol-use disorder. ${ }^{9}$ Anticancer medications, especially taxanes, are also known to cause neuropathy. A study found that $100 \%$ of patients receiving paclitaxel developed
Correspondence: Richard M van Rijn Department of Medicinal Chemistry and Molecular Pharmacology, Purdue University, 575 Stadium Mall Drive, West Lafayette, IN 47907, USA

Tel + I $765494646 \mid$

Fax +I 765494 |4I4

Email rvanrijn@purdue.edu 
symptoms of neuropathy. ${ }^{10}$ On a clinical level, NeuP translates to a complex syndrome that is often multidrug-resistant and unresponsive to alternative therapies. Therefore, it is imperative that clinicians understand the etiology of NeuP and the mechanism and effectiveness of the current repertoire of treatments.

\section{Significance and limitations}

In this integrative review, an internal medicine physician and preclinical behavioral pharmacologist summarize differences and overlap in etiologies and treatment options for NeuP. This review focuses on three of the most common neuropathies - diabetic, alcohol-induced, and drug-induced neuropathy - describes the specific nerve fibers associated with each neuropathy, and lists recommended treatment options for NeuP. The review is purposely succinct, aimed at providing clinicians with insight into the etiology of NeuP and educating preclinical scientists on the diagnosis and choice of treatment for NeuP. The review favors conciseness over an extensive in-depth analysis of the available literature, thus limiting its scope.

\section{Materials and methods}

A PubMed search was performed to identify clinical and preclinical studies detailing etiology and treatment of NeuP. Emphasis was given to articles published in the last 10 years, with older articles used primarily to provide a frame of reference.

\section{Basic anatomy of pain}

Comprehending the pathophysiology of peripheral neuropathy and the mechanism of action for drugs requires a basic appreciation of the anatomy of the somatosensory system, especially with respect to pain. Noxious stimuli, such as thermal, chemical, and high-threshold mechanical stimuli, are detected in the periphery and conducted to the spinal cord via two types of small fibers. The $\mathrm{C}$ fibers are unmyelinated, slow-conducting, and localize pain poorly. The $A \delta$ fibers are thinly myelinated, faster-conducting, and localize pain better. ${ }^{11,12}$ Larger and more thickly myelinated than $A \delta$ fibers are $A \alpha$ and $A \beta$ fibers, which primarily transmit information about proprioception and vibration. ${ }^{13}$ It is primarily the $\mathrm{A} \delta$ and $\mathrm{C}$ fibers that are indiscriminately affected in the different types of neuropathies (Figure 1). Measuring which type of fibers are impacted is not trivial, but can be attempted by clinical examination; loss of tactile or vibratory skin sensation or tendon reflexes are indicative of large-fiber neuropathy, whereas alterations in lower-limb pinprick sensation and a visual analog scale pain score $>40$ suggest small-fiber neuropathy. ${ }^{14}$ Small-fiber neuropathy can also be determined by measuring intraepidermal nerve-fiber density following biopsy. ${ }^{15} \mathrm{~A} \delta$-fiber neuropathy can be mea-

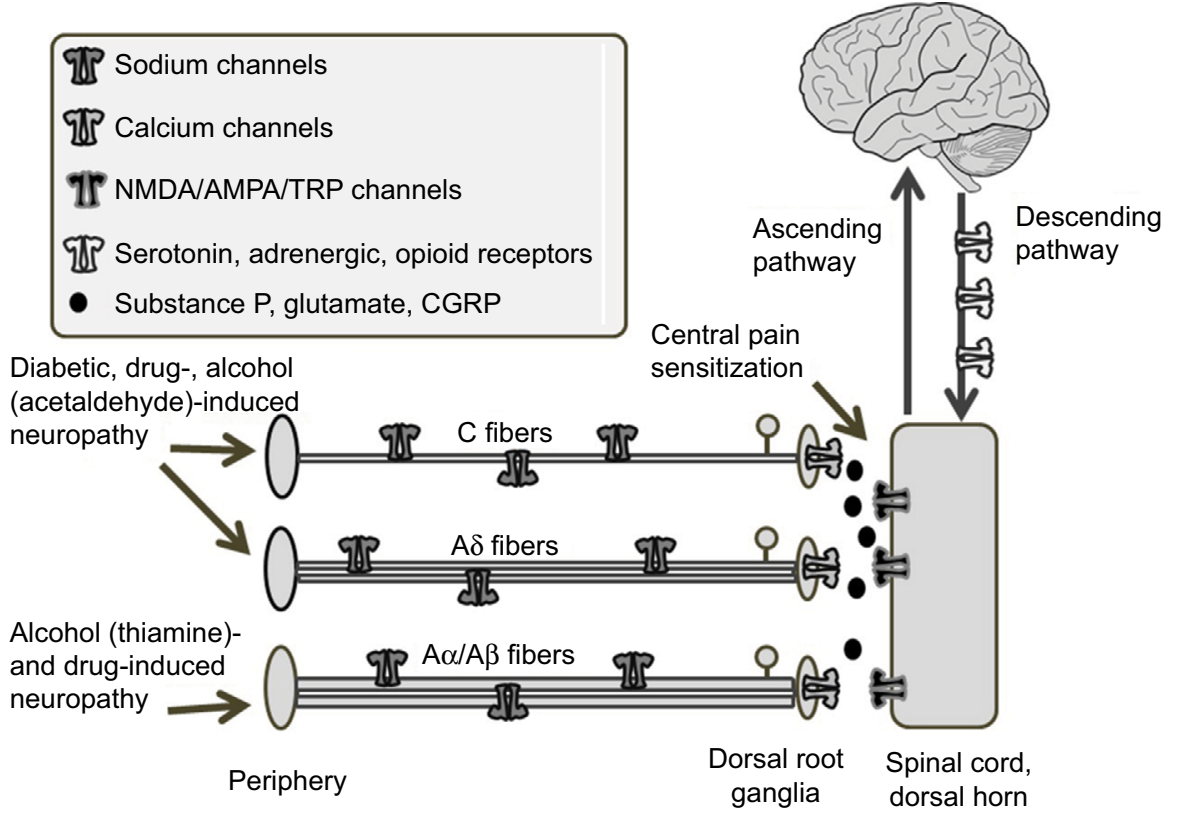

Figure I Overview of neuropathies affecting pain pathways.

Notes: $C$ and $A \delta$ fibers are affected by diabetes, drugs, and alcohol (and its metabolite acetaldehyde), whereas large, myelinated $A \alpha$ and $A \beta$ fibers are affected by drugs and thiamine deficiency. Channels (sodium, calcium) and receptors (NMDA, serotonin, adrenergic, opioid) along the pain pathway serve as drug targets for treatment of chronic neuropathic pain.

Abbreviations: NMDA, N-methyl-D-aspartate; AMPA, $\alpha$-amino-3-hydroxy-5-methyl-4-isoxazolepropionic acid; TRP, transient receptor potential; CGRP, calcitonin generelated peptide. 
sured noninvasively by laser evoked-potential ${ }^{16,17}$ and contact heat-evoked potential. ${ }^{18,19}$ Nerve-conducting studies are a useful technique for NeuP research, but less relevant for clinical studies, as they primarily measure $A \beta$-fiber function, which supersedes small-fiber neuropathy ${ }^{20}$ and is laborious. ${ }^{21}$

Receptors on primary sensory neurons convert environmental stimuli, such as pain, into an electrical signal that is transmitted to the dorsal root ganglia, with an important role for sodium channels. ${ }^{22,23}$ In the terminals of the dorsal root ganglia, neurons subsequently convert this electric signal into chemical signals by releasing neurotransmitters and neuropeptides, including glutamate, substance $\mathrm{P}$, and calcitonin gene-related peptide into the dorsal horn (Figure 1). A significant event that occurs during the development of a chronic pain state is central sensitization, where postsynaptic glutamate ( $\alpha$-amino-3-hydroxy-5-methyl-4-isoxazolepropionic acid [AMPA] and $N$-methyl-D-aspartate [NMDA]) receptors become increasingly more adaptive in transmitting pain signals. ${ }^{24-28}$ Activation of presynaptic calcium channels can reduce the release of neurotransmitters and dampen central sensitization (Figure 1). ${ }^{29,30}$ In the spinal cord, this nociceptive signal can be modulated by inhibitory interneurons using $\gamma$-aminobutyric acid (GABA) and glycine as their main neurotransmitters. Following the reception of a pain signal in the cortical structures of the brain, the experience of pain can still be suppressed by a descending system that originates from the brain stem. This efferent system attenuates the afferent signal via neurotransmitters, such as endogenous opioids, serotonin, and noradrenaline. ${ }^{31-33}$

\section{Diagnosis of neuropathic pain}

The diagnosis of NeuP is usually made on clinical grounds. Screening questionnaires are available for NeuP, including the Leeds Assessment of Neuropathic Symptoms and Signs, ${ }^{34}$ PainDetect, ${ }^{35}$ and Douleur Neuropathique 4 (DN4). ${ }^{36}$ Of these, the DN4 has the higher sensitivity and specificity. The DN4 is a questionnaire that consists of four questions and incorporates both subjective and objective information, namely the patient's perception of pain and the physician's exam findings. It has been validated as a screening tool for different types of NeuP, including diabetic neuropathy, and has sensitivity and specificity of $80 \%$ and $92 \%$, respectively, at a score cutoff of $4 .{ }^{36}$ At a score cutoff of 3 , sensitivity and specificity are $84 \% .{ }^{36}$ While these screening tools are useful, the diagnosis ultimately hinges on the clinician's intuition from effective interviewing and physical examination. Symptoms of neuropathy can range from hypoalgesia and paresthesia (tingling) to hyperalgesia, especially prominent in the distal extremities, known as the "stocking and glove" distribution. Patients with neuropathy may exhibit a painful response to benign stimuli, such as light touch from a cotton swab or a finger. Patients may also exhibit an attenuated/ exaggerated response to a pinprick. These phenomena are known as allodynia and hypo/hyperalgesia, respectively. As the neuropathy progresses, more severe symptoms, including burning sensations and electric shocks, can arise. Symptoms are aggravated during rest and prolonged weakness and sensory loss in extremities; particularly feet can culminate in gait impairment. ${ }^{37}$ Because the diagnosis is based on subjective data, it can sometimes be challenging for the physician to track response to therapeutics. With this said, the threshold to treat NeuP is exceedingly low, given the good side-effect profile of most drugs. In our experience, most physicians would trial a serotonin-norepinephrine reuptake inhibitor (SNRI) if a patient complained of burning pain, even if no other findings were present.

\section{Three major types of neuropathy Diabetic neuropathy}

Peripheral neuropathy is one of the most common microvascular complications of diabetes. It has been estimated that $\sim 50 \%$ of diabetics suffer from peripheral neuropathy, ${ }^{38}$ and $50 \%$ of these neuropathies are considered at least moderate in severity. ${ }^{39-41}$ Histological studies suggest that primarily small $\mathrm{C}$ fibers are affected by diabetes and glucose intolerance, ${ }^{42-45}$ although $A \delta$ fibers have also been shown to be affected by type 1 and type 2 diabetes. ${ }^{46-48}$ Morbidities associated with diabetic neuropathy amount to more than $\$ 10$ billion in the $\mathrm{US}^{49}$

Diabetes or glucose intolerance can impair vasodilation and lead to ischemia, which is thought to be central to the pathogenesis of peripheral neuropathy, including trigeminal neuralgia. ${ }^{50,51} \mathrm{~A}$ recent study demonstrated that patients with glucose intolerance, even without carrying the diagnosis of diabetes, exhibited C-fiber neuropathy, highlighting the devastating effect of prolonged hyperglycemia on neuronal health. ${ }^{52}$ On a molecular level, there are at least five prevailing mechanisms of how hyperglycemia leads to different complications of diabetes, with the polyol and PARP pathways being the most relevant to neuronal death. ${ }^{53}$ In the polyol pathway, the influx of glucose into the cell activates aldose reductase to convert glucose to sorbitol. Sorbitol is then converted to fructose via sorbitol dehydrogenase. Both of these steps generate oxidative species that contribute to neuronal injury. ${ }^{53,54}$ In Schwann cells, endothelial cells, and sensory neurons, PARP is stimulated by oxidative species and induces 
further oxidative stress in a feedback mechanism. ${ }^{55-59}$ PARP is a nuclear enzyme that can also alter gene expression, leading to impairment of neuronal conduction velocity, small-fiber neuropathy (Figure 1), hyperalgesia, and allodynia, as well as other diabetic complications. . $^{53,55,60-64}$

\section{Alcoholic neuropathy}

The prevalence of alcohol-related peripheral neuropathy has been estimated to occur in two-thirds of chronic alcoholics. $^{9}$ Alcohol-related peripheral neuropathy is historically regarded as a large-fiber neuropathy from thiamine deficiency (Figure 1). ${ }^{65-69}$ In contrast to small sensory fibers, large fibers are responsible for vibration and proprioception. However, advances in scientific techniques have reshaped the pathophysiology of alcoholic neuropathy. Observations that neuropathy can develop even in the setting of normal thiamine levels ${ }^{70}$ and that the early stages of alcoholic neuropathy are characterized by painful paresthesia ${ }^{71}$ have led scientists to postulate that alcohol and its metabolites have direct neurotoxic effects on small C fibers (Figure 1). ${ }^{72,73}$ Acetaldehyde is a known neurotoxin that is formed when alcohol is metabolized by alcohol dehydrogenase. The precise mechanism underlying alcoholic neuropathy is yet to be fully elucidated. Some proposed explanations include direct neurotoxic effects of alcohol or its metabolite acetaldehyde ${ }^{70}$ through activation of spinal cord microglia, ${ }^{74}$ involvement of metabotropic glutamate 5 and opioid receptors ${ }^{74,75}$ in the spinal cord, promotion of oxidative stress by the activity of alcohol-metabolizing enzymes in the liver, ${ }^{76}$ and release of proinflammatory cytokines coupled with phosphorylation of protein kinase $\mathrm{C}^{77}$ and extracellular signal-regulated kinases. ${ }^{78}$ Taken together, these different initiating events may ultimately lead to DNA fragmentation and neuronal apoptosis. ${ }^{79}$ Once formed, acetaldehyde is metabolized by ALDH into a much less harmful acetate. Interestingly, pharmacological and genetic data suggest that reducing ALDH activity can precipitate peripheral neuropathy, whereas increasing its activity may carry therapeutic potential. As such, disulfiram, an ALDH inhibitor, has the side effect of causing NeuP. ${ }^{80}$

\section{Medication-induced neuropathy}

Disulfiram is not unique in causing NeuP; in fact, many and more commonly prescribed drugs, which span the spectrum of chemotherapy to cardiovascular medications, are known to induce neuropathy. This section focuses on taxanes, with mention of statin-induced neuropathy. Paclitaxel and docetaxel are antineoplastic taxanes used to treat numerous types of solid tumors, including ovarian, breast, lung, and head and neck malignancies. Paclitaxel has its chemotherapeutic effect by promoting microtubule assembly in a disorganized manner, thereby prohibiting mitotic division. It is by this very same mechanism that paclitaxel causes peripheral neuropathy, one of the most common and limiting side effects of the drug. In vivo studies have demonstrated that paclitaxel causes abnormal microtubule accumulation, leading to demyelination, ${ }^{81,82}$ and inhibits the regenerative capacities of neurons. ${ }^{83,84}$ In a non-dose-dependent manner, paclitaxel causes hyperalgesia and allodynia without affecting motor performance. ${ }^{85} \mathrm{Clini}$ cally, patients have complained of sensory neuropathy and decreased vibration and proprioception, indicating that both small $\mathrm{C}$ and $\mathrm{A} \delta$ fibers are affected (Figure 1). ${ }^{86-89}$ One of the original articles on paclitaxel-induced neuropathy studied paclitaxel infusion at three doses, and found that neuropathy developed in $>80 \%$ of the patients at all doses and was doselimiting in $70 \%$ of patients at the highest dose. ${ }^{90}$

It is noteworthy that diabetes is a predisposition to druginduced neuropathy. In a retrospective study comparing the rates of taxane-induced neuropathy, chronic diabetics (defined by $>5$ years) developed neuropathy more frequently compared to nondiabetics. ${ }^{91}$ With regard to treating chemotherapy-induced peripheral neuropathy, SNRIs have been shown to be superior to placebo. ${ }^{92}$ These drugs are also used in the treatment of diabetic neuropathy. Together, these data suggest that taxanes and diabetes act differently but synergistically in causing peripheral nerve damage and NeuP.

Statins are prescribed to $>40$ million patients in the US alone (https://meps.ahrq.gov), and are frequently prescribed to diabetics to reduce their cardiovascular risk. It is interesting to note that there have been reports of statin-induced peripheral neuropathy. ${ }^{93,94}$ Though statins are demonstrated to have pleiotropic effects, preclinical studies suggest that they can attenuate NeuP by potentiating antioxidation. ${ }^{95,96}$ Promising data have also been found in human studies where rosuvastatin improved both the intensity of diabetic neuropathy pain and nerve conduction. ${ }^{97}$ In combination with the rarity of statin-induced neuropathy, these data suggest that this potential side effect of statin should minimally influence the physician's decision to prescribe statins for vascular protection.

\section{Current neuropathic pain therapies}

Based on a 2015 analysis of a systemic review and metaanalysis performed by the Neuropathic Pain Special Interest Group on clinical studies of NeuP pharmacotherapy, a new guideline for treatment of NeuP was recently proposed. ${ }^{98}$ The guidelines highlight the difficulty in adequately treating NeuP, 
but recommend the use of tricyclic antidepressants (TCAs), SNRIs, pregabalin, and gabapentin as first-line treatment options for NeuP. ${ }^{98}$ In the following section, we discuss these medications in more detail.

\section{Tricyclic antidepressants}

A number of randomized controlled trials have shown that TCAs may exert their NeuP-relieving effect via multiple mechanisms of action. ${ }^{99,100}$ The potential of TCAs in pain relief is primed by their inhibition of presynaptic reuptake of serotonin and norepinephrine ${ }^{101,102}$ and activity at NMDA receptors and sodium channels, ${ }^{103}$ all of which are involved in pain transmission. Amitriptyline and nortriptyline are two of the oldest TCAs on the market. Although their use to treat depression has declined with the increased popularity of SNRIs and selective serotoninreuptake inhibitors, they continue to be used off-label to treat NeuP. However, according to recent Cochrane meta-analyses, no high-quality evidence exists to support the analgesic effect of both amitriptyline and nortriptyline, despite an extensive history of anecdotal success. ${ }^{104,105} \mathrm{~A}$ factor for the declining use of TCAs, whether for depressive disorders or NeuP, is that TCAs have a higher risk for fatal overdose and require careful dosing. Therefore, TCAs should not be advocated for use as first-line treatment of NeuP.

\section{Serotonin-norepinephrine reuptake inhibitors}

Venlafaxine and duloxetine are SNRIs that are prescribed to treat depression, anxiety, and NeuP. Serotonin and norepinephrine play integral parts in the descending pain pathway to suppress pain. ${ }^{106-108}$ Preclinical and clinical research has shown that drugs that increase serotonergic and noradrenergic neurotransmissions exert antinociceptive properties. For example, SNRIs significantly attenuated pain-related behaviors in the formalin model of persistent pain and the L5-L6 spinal nerve ligation model of NeuP in rats. ${ }^{109}$ SNRIs are also efficacious in the treatment of pain and functional impairment associated with fibromyalgia, as per a number of randomized controlled trials. ${ }^{110-113}$

Pharmacological studies have demonstrated that for certain SNRIs, serotonin reuptake inhibition predominates at low drug concentration, whereas inhibition of norepinephrine reuptake occurs only at much higher doses. ${ }^{114}$ Unlike treating depression, the treatment for NeuP with SNRIs is achieved at higher doses and more rapidly. For venlafaxine, the usual antidepressant dosage is much lower than what is needed for pain relief, ${ }^{115}$ suggesting that norepinephrine contributes more strongly to attenuating pain. The importance of norepinephrine is further exemplified by the effect of clonidine and the adrenergic receptor agonist in alleviating pain. ${ }^{116}$ However, a Cochrane review found that venlafaxine had limited efficacy compared to placebo. ${ }^{32}$ Despite relatively similar pharmacology, duloxetine was effective for the relief of NeuP. ${ }^{117}$ Duloxetine is a much more potent inhibitor of the serotonin- and norepinephrine reuptake transporters than venlafaxine. ${ }^{114}$ Therefore, when choosing an SNRI, we would favor the use of duloxetine.

\section{Calcium-channel blockers}

Changes in the expression and activity of voltage-gated calcium channels are known to modulate neuronal excitability and synaptic plasticity in the dorsal horn, culminating in pain processing. ${ }^{118-120} \mathrm{The}_{\mathrm{Ca}} \alpha_{2} \delta_{1}$ subunit, an important accessory subunit for calcium channels, plays an important role in NeuP development, based on reports of increased expression in the dorsal root ganglia and spinal neurons during NeuP states. ${ }^{121-123}$ Further supporting evidence shows that blockade of the $\mathrm{Ca}_{\mathrm{v}} \alpha_{2} \delta_{1}$ subunit could reverse tactile allodynia in nerveinjured animals. ${ }^{124,125}$ Interestingly, the $\mathrm{Ca}_{\mathrm{v}} \alpha_{2} \delta_{1}$ subunit is the binding site for pregabalin and gabapentin. ${ }^{126}$ Pregabalin and gabapentin were developed and US Food and Drug Administration (FDA) approved for treatment of epilepsy, but have become first-line treatments for NeuP.

A Cochrane review using randomized double-blind trials found pregabalin to be effective for the treatment of NeuP. Pregabalin at doses of $>300 \mathrm{mg}$ provided moderate pain relief (50\% improvement from baseline) in different types of pain. ${ }^{127}$ Another Cochrane review investigated the efficacy of gabapentin on NeuP using randomized double-blind controlled studies, and concluded that 1,200 $\mathrm{mg}$ daily was needed to achieve $50 \%$ pain relief. This effect was found in $35 \%$ of study participants compared to $21 \%$ in the placebo group. ${ }^{128}$ To avoid sedating effects, gabapentin is divided into three doses, and patients are routinely instructed to titrate the dose, starting at $300 \mathrm{mg}$ daily. However, compliance is a major issue in patients on gabapentin, usually as they dismiss the medications as ineffective and discontinue the medications before reaching the therapeutic dose. Therefore, it is prudent to educate patients of this therapeutic range. Moreover, a recent study has shown that the endogenous lipid palmitoylethanolamide has synergistic effects with gabapentin to relieve chemotherapy-induced allodynia in mice, which makes it possible to reduce the dosage of gabapentin and lower its side effects. ${ }^{13}$ 
To illustrate further the vital role of calcium channels in pain transmission, ziconotide is a selective calcium-channel blocker and potent analgesic. Ziconotide is FDA approved for the treatment of refractory chronic pain. ${ }^{129}$ As ziconotide is a large peptide that cannot readily cross the blood-brain barrier, it can thus only be administered intrathecally. Intrathecal drug delivery can be used to manage chronic pain effectively, and may provide the most targeted approach with the fewest side effects. ${ }^{130-133}$

\section{Opioids and drug development}

Although opioids are intended for short-term use for acute pain, they have repeatedly been used to treat chronic pain. For example, tramadol has been used to treat chronic pain, in part due to its dual action as a $\mu$-opioid agonist and SNRI.$^{98}$ Patients frequently cite failures of different adjunctive therapies to alleviate their pain, and revert to the use of opioids. In light of the rapid increase in patients suffering from opioid-dependence/ use disorders, the Centers for Disease Control and Prevention (CDC) has recently published guidelines to avoid routinely prescribing narcotics for the management of chronic pain. In addition to dependence, opioids also cause other serious side effects, including tolerance, ileus, and respiratory depression. The latter side effect explains the high hospitalization and mortality rate associated with opioid overdose, which has increased concomitantly with the rise in opioid dependence. Moreover, prolonged use of (escalating doses of) opioids can lead to paradoxical pain, also known as opioid-induced hyperalgesia, and discontinuation of opioids leads to withdrawal of hyperalgesia. While the CDC guidelines are helpful for guiding narcotic use, it will be challenging to unearth the culture of pain management that is heavily rooted in narcotics. The CDC currently excludes these guidelines from patients with active malignancy, which remains a challenge to treat, despite rapidly escalating doses of opioids. Clearly, safer and more potent and selective therapeutics are necessary and overdue. Although the $\mathrm{CDC}$ raised concerns regarding the use of $\mu$-opioids in chronic pain, it is important not to dismiss completely their analgesic potential for acute pain and palliative care. ${ }^{134}$ Importantly, other opioid-receptor subtypes like $\mu$ are also expressed along descending pain pathways, and increasing research efforts have identified these non- $\mu$-opioid receptors as potential analgesic targets for chronic pain.

While current analgesic opioids target $\mu$-opioid receptors, there are three other opioid-receptor subtypes. One of the most intriguing new developments in the use of opioids for NeuP comes from work focused on $\delta$-opioid receptors (DORs), א-ORs (KORs), and nociception ORs (NORs). DORs, KORs, and NORs are expressed in several levels of pain pathways, including the periphery, spinal cord, and supraspinal regions. ${ }^{135-141}$ The expression of opioid-peptide messenger RNA also increases under conditions of chronic pain. ${ }^{142-144}$ Preclinical evidence has demonstrated that inhibition of DORs or KORs via either opioid antagonists or genetic ablation in mice enhances allodynia and hyperalgesia following spinal cord injury. ${ }^{145-148}$ Additionally, both DOR and KOR agonists have elicited antinociceptive and antiallodynic effects in animal models of NeuP. ${ }^{142,149-151}$ An intriguing recent study identified 6-methoxyflavanone as a positive allosteric modulator of $\mathrm{GABA}_{\mathrm{A}}$ channels that can alleviate streptozotocin-induced diabetic NeuP in female rats in a naloxone-reversible manner, potentially via direct interaction with DORs and KORs. ${ }^{152}$ In contrast, the role of NORs in nociception is less linear: analgesic actions of the nociceptin system in rodents are bidirectional, depending upon the doses and assays. ${ }^{153-156}$ Encouragingly, the activation of NORs produces only attenuated and not intensified pain in primates regardless of experimental conditions, ${ }^{157,158}$ and thus their therapeutic potential in humans remains.

\section{Summary}

NeuP results from nerve damage, and can be classified based on the inciting factors, such as hyperglycemia (as in diabetes), toxins from alcohol metabolism, and drugs like chemotherapy. In basic pain anatomy, noxious stimuli are detected in the periphery, and are transmitted via small fibers to the central nervous system, where they are converted into the experience of pain (Figure 1). This afferent system is modulated by an efferent system via GABAergic neurons and neurotransmitters, such as serotonin and norepinephrine. Opioids that act on GABAergic neurons have been used in pain relief for millennia. However, the side effects of opioids, especially their addictive properties, have recently led the CDC to advise against their use in chronic pain. Therefore, an understanding of adjunctive therapies for NeuP is essential. Meta-analyses show the most promising efficacy in calcium-channel ligands and SNRIs over older TCAs, but these medications still leave a number of patients untreated. Sodium-channel blockers may represent a broadly applicable strategy for many types of NeuP. ${ }^{159-162}$ However, improved diagnosis of symptoms paired with increased understanding and detection of the exact fibers affected by disease-specific neuropathies may guide the development of more precise therapeutics. ${ }^{163}$ Targeting receptors or ion channels that are uniquely expressed in $\mathrm{A} \beta, \mathrm{A} \delta$, or $\mathrm{C}$ fibers, including DORs and transient receptor-potential (TRPV, TRPA1) channels ${ }^{164-166}$ may represent a new direction for NeuP treatment. 


\section{Acknowledgments}

RMvR receives funding from the National Institute on Alcohol Abuse and Alcoholism (R00AA020539) and the Ralph W and Grace M Showalter Research Trust.

\section{Disclosure}

The authors report no conflicts of interest in this work.

\section{References}

1. Jensen TS, Baron R, Haanpää M, et al. A new definition of neuropathic pain. Pain. 2011;152(10):2204-2205.

2. Gustorff B, Dorner T, Likar R, et al. Prevalence of self-reported neuropathic pain and impact on quality of life: a prospective representative survey. Acta Anaesthesiol Scand. 2008;52(1):132-136.

3. Bouhassira D, Lanteri-Minet M, Attal N, Laurent B, Touboul C. Prevalence of chronic pain with neuropathic characteristics in the general population. Pain. 2008;136(3):380-387.

4. Torrance N, Smith BH, Bennett MI, Lee AJ. The epidemiology of chronic pain of predominantly neuropathic origin: results from a general population survey. J Pain. 2006;7(4):281-289.

5. van Hecke O, Austin SK, Khan RA, Smith BH, Torrance N. Neuropathic pain in the general population: a systematic review of epidemiological studies. Pain. 2014;155(4):654-662.

6. Baron R, Forster M, Binder A. Subgrouping of patients with neuropathic pain according to pain-related sensory abnormalities: a first step to a stratified treatment approach. Lancet Neurol. 2012; 11(11):999-1005.

7. Menke A, Casagrande S, Geiss L, Cowie CC. Prevalence of and trends in diabetes among adults in the United States, 1988-2012. JAMA. 2015;314(10):1021-1029.

8. American Diabetes Association. Available from: http://diabetes.org/. Accessed January 13, 2017.

9. Ammendola A, Tata MR, Aurilio C, et al. Peripheral neuropathy in chronic alcoholism: a retrospective cross-sectional study in 76 subjects. Alcohol Alcohol. 2001;36(3):271-275.

10. Loprinzi CL, Reeves BN, Dakhil SR, et al. Natural history of paclitaxelassociated acute pain syndrome: prospective cohort study NCCTG N08C1. J Clin Oncol. 2011;29(11):1472-1478.

11. Beissner F, Brandau A, Henke $C$, et al. Quick discrimination of $A_{\text {delta }}$ and $\mathrm{C}$ fiber mediated pain based on three verbal descriptors. PloS One. 2010;5(9):e12944.

12. McGlone F, Reilly D. The cutaneous sensory system. Neurosci Biobehav Rev. 2010;34(2):148-159.

13. Hoitsma E, Reulen JP, de Baets M, Drent M, Spaans F, Faber CG. Small fiber neuropathy: a common and important clinical disorder. J Neurol Sci. 2004;227(1):119-130.

14. Lefaucheur JP, Creange A. Neurophysiological testing correlates with clinical examination according to fibre type involvement and severity in sensory neuropathy. J Neurol Neurosurg Psychiatry. 2004; 75(3):417-422.

15. Lauria G, Morbin M, Lombardi R, et al. Axonal swellings predict the degeneration of epidermal nerve fibers in painful neuropathies. Neurology. 2003;61(5):631-636.

16. Magerl W, Ali Z, Ellrich J, Meyer RA, Treede RD. C- and A $\delta$-fiber components of heat-evoked cerebral potentials in healthy human subjects. Pain. 1999;82(2):127-137.

17. Treede RD, Lorenz J, Baumgartner U. Clinical usefulness of laserevoked potentials. Neurophysiol Clin. 2003;33(6):303-314.

18. Granovsky Y, Matre D, Sokolik A, Lorenz J, Casey KL. Thermoreceptive innervation of human glabrous and hairy skin: a contact heat evoked potential analysis. Pain. 2005;115(3):238-247.

19. Chen AC, Niddam DM, Arendt-Nielsen L. Contact heat evoked potentials as a valid means to study nociceptive pathways in human subjects. Neurosci Lett. 2001;316(2):79-82.
20. Breiner A, Lovblom LE, Perkins BA, Bril V. Does the prevailing hypothesis that small-fiber dysfunction precedes large-fiber dysfunction apply to type 1 diabetic patients? Diabetes Care. 2014;37(5):1418-1424.

21. England JD, Gronseth GS, Franklin G, et al. Distal symmetric polyneuropathy: a definition for clinical research. Neurology. 2005;64(2):199-207.

22. Rush AM, Cummins TR, Waxman SG. Multiple sodium channels and their roles in electrogenesis within dorsal root ganglion neurons. J Physiol. 2007;579(Pt 1):1-14.

23. Wang W, Gu J, LiYQ, Tao YX. Are voltage-gated sodium channels on the dorsal root ganglion involved in the development of neuropathic pain? Mol Pain. 2011;7:16.

24. Woolf CJ, Thompson SW. The induction and maintenance of central sensitization is dependent on N-methyl-D-aspartic acid receptor activation; implications for the treatment of post-injury pain hypersensitivity states. Pain. 1991;44(3):293-299.

25. Ultenius C, Linderoth B, Meyerson BA, Wallin J. Spinal NMDA receptor phosphorylation correlates with the presence of neuropathic signs following peripheral nerve injury in the rat. Neurosci Lett. 2006; 399(1-2):85-90.

26. Lu Y, Sun YN, Wu X, et al. Role of $\alpha$-amino-3-hydroxy-5-methyl-4isoxazolepropionate (AMPA) receptor subunit GluR1 in spinal dorsal horn in inflammatory nociception and neuropathic nociception in rat. Brain Res. 2008;1200:19-26.

27. Park JS, Yaster M, Guan X, et al. Role of spinal cord $\alpha$-amino-3hydroxy-5-methyl-4-isoxazolepropionic acid receptors in complete Freund's adjuvant-induced inflammatory pain. Mol Pain. 2008;4:67.

28. Latremoliere A, Woolf CJ. Central sensitization: a generator of pain hypersensitivity by central neural plasticity. J Pain. 2009;10(9):895-926.

29. Jørum E, Warncke T, Stubhaug A. Cold allodynia and hyperalgesia in neuropathic pain: the effect of N-methyl-D-aspartate (NMDA) receptor antagonist ketamine - a double-blind, cross-over comparison with alfentanil and placebo. Pain. 2003;101(3):229-235.

30. Chizh BA, Göhring M, Tröster A, Quartey GK, Schmelz M, Koppert W. Effects of oral pregabalin and aprepitant on pain and central sensitization in the electrical hyperalgesia model in human volunteers. Br J Anaesth. 2007;98(2):246-254.

31. Al-Hasani R, Bruchas MR. Molecular mechanisms of opioid receptordependent signaling and behavior. Anesthesiology. 2011;115(6):1363-1381.

32. Gallagher HC, Gallagher RM, Butler M, Buggy DJ, Henman MC Venlafaxine for neuropathic pain in adults. Cochrane Database Syst Rev. 2015;(8):CD011091.

33. Basbaum AI, Fields HL. Endogenous pain control systems: brainstem spinal pathways and endorphin circuitry. Annu Rev Neurosci. 1984;7:309-338.

34. Bennett M. The LANSS pain scale: the Leeds assessment of neuropathic symptoms and signs. Pain. 2001;92(1-2):147-157.

35. Freynhagen R, Baron R, Gockel U, Tolle TR. PainDetect: a new screening questionnaire to identify neuropathic components in patients with back pain. Curr Med Res Opin. 2006;22(10):1911-1920.

36. Spallone V, Morganti R, D'Amato C, Greco C, Cacciotti L, Marfia GA. Validation of DN4 as a screening tool for neuropathic pain in painful diabetic polyneuropathy. Diabet Med. 2012;29(5):578-585.

37. Hawley RJ, Kurtzke JF, Armbrustmacher VW, Saini N, Manz H. The course of alcoholic-nutritional peripheral neuropathy. Acta Neurol Scand. 1982;66(5):582-589.

38. Boulton AJ, Vinik AI, Arezzo JC, et al. Diabetic neuropathies: a statement by the American Diabetes Association. Diabetes Care. 2005;28(4):956-962.

39. Davies M, Brophy S, Williams R, Taylor A. The prevalence, severity, and impact of painful diabetic peripheral neuropathy in type 2 diabetes. Diabetes Care. 2006;29(7):1518-1522.

40. DiBonaventura MD, Cappelleri JC, Joshi AV. Association between pain severity and health care resource use, health status, productivity and related costs in painful diabetic peripheral neuropathy patients. Pain Med. 2011;12(5):799-807.

41. Sadosky A, Schaefer C, Mann R, et al. Burden of illness associated with painful diabetic peripheral neuropathy among adults seeking treatment in the US: results from a retrospective chart review and cross-sectional survey. Diabetes Metab Syndr Obes. 2013;6:79-92. 
42. Orstavik K, Namer B, Schmidt R, et al. Abnormal function of C-fibers in patients with diabetic neuropathy. JNeurosci. 2006;26(44):11287-11294.

43. Pittenger GL, Ray M, Burcus NI, McNulty P, Basta B, Vinik AI. Intraepidermal nerve fibers are indicators of small-fiber neuropathy in both diabetic and nondiabetic patients. Diabetes Care. 2004;27(8):1974-1979.

44. Polydefkis M, Hauer P, Sheth S, Sirdofsky M, Griffin JW, McArthur JC. The time course of epidermal nerve fibre regeneration: studies in normal controls and in people with diabetes, with and without neuropathy. Brain. 2004;127(Pt 7):1606-1615.

45. Smith AG, Ramachandran P, Tripp S, Singleton JR. Epidermal nerve innervation in impaired glucose tolerance and diabetes-associated neuropathy. Neurology. 2001;57(9):1701-1704.

46. Chao CC, Tseng MT, Lin YJ, et al. Pathophysiology of neuropathic pain in type 2 diabetes: skin denervation and contact heat-evoked potentials. Diabetes Care. 2010;33(12):2654-2659.

47. Løseth S, Stålberg EV, Lindal S, Olsen E, Jorde R, Mellgren SI. Small and large fiber neuropathy in those with type 1 and type 2 diabetes: a 5-year follow-up study. J Peripher Nerv Syst. 2016;21(1):15-21.

48. Jagodic MM, Pathirathna S, Nelson MT, et al. Cell-specific alterations of T-type calcium current in painful diabetic neuropathy enhance excitability of sensory neurons. J Neurosci. 2007;27(12):3305-3316.

49. Gordois A, Scuffham P, Shearer A, Oglesby A, Tobian JA. The health care costs of diabetic peripheral neuropathy in the US. Diabetes Care. 2003;26(6):1790-1795.

50. Gordon Smith A, Robinson Singleton J. Idiopathic neuropathy, prediabetes and the metabolic syndrome. J Neurol Sci. 2006;242(1-2):9-14.

51. Xu Z, Zhang P, Long L, He H, Zhang J, Sun S. Diabetes mellitus in classical trigeminal neuralgia: a predisposing factor for its development. Clin Neurol Neurosurg. 2016;151:70-72.

52. Green AQ, Krishnan S, Finucane FM, Rayman G. Altered C-fiber function as an indicator of early peripheral neuropathy in individuals with impaired glucose tolerance. Diabetes Care. 2010;33(1):174-176.

53. Edwards JL, Vincent AM, Cheng HT, Feldman EL. Diabetic neuropathy: mechanisms to management. Pharmacol Ther. 2008;120(1):1-34.

54. Brownlee M. Biochemistry and molecular cell biology of diabetic complications. Nature. 2001;414(6865):813-820.

55. Obrosova IG, Drel VR, Pacher P, et al. Oxidative-nitrosative stress and poly(ADP-ribose) polymerase (PARP) activation in experimental diabetic neuropathy: the relation is revisited. Diabetes. 2005; 54(12):3435-3441.

56. Southan GJ, Szabo C. Poly(ADP-ribose) polymerase inhibitors. Curr Med Chem. 2003;10(4):321-340.

57. Du X, Matsumura T, Edelstein D, et al. Inhibition of GAPDH activity by poly(ADP-ribose) polymerase activates three major pathways of hyperglycemic damage in endothelial cells. J Clin Invest. 2003;112(7):1049-1057.

58. Soriano FG, Virág L, Jagtap P, et al. Diabetic endothelial dysfunction: the role of poly(ADP-ribose) polymerase activation. Nat Med. 2001;7(1):108-113.

59. Ha HC, Hester LD, Snyder SH. Poly(ADP-ribose) polymerase-1 dependence of stress-induced transcription factors and associated gene expression in glia. Proc Natl Acad Sci USA. 2002;99(5):3270-3275.

60. Ilnytska O, Lyzogubov VV, Stevens MJ, et al. Poly(ADP-ribose) polymerase inhibition alleviates experimental diabetic sensory neuropathy. Diabetes. 2006;55(6):1686-1694.

61. Li F, Drel VR, Szabó C, Stevens MJ, Obrosova IG. Low-dose poly(ADPribose) polymerase inhibitor-containing combination therapies reverse early peripheral diabetic neuropathy. Diabetes. 2005;54(5):1514-1522.

62. Obrosova IG, Li F,Abatan OI, et al. Role of poly(ADP-ribose) polymerase activation in diabetic neuropathy. Diabetes. 2004;53(3):711-720.

63. Pacher P, Liaudet L, Soriano FG, Mabley JG, Szabó E, Szabó C. The role of poly(ADP-ribose) polymerase activation in the development of myocardial and endothelial dysfunction in diabetes. Diabetes. 2002;51(2):514-521.

64. Zheng L, Szabo C, Kern TS. Poly(ADP-ribose) polymerase is involved in the development of diabetic retinopathy via regulation of nuclear factor-кB. Diabetes. 2004;53(11):2960-2967.
65. Abe T, Itokawa Y. Effect of ethanol administration on thiamine metabolism and transketolase activity in rats. Int J Vitam Nutr Res. 1977;47(4):307-314.

66. Frank O, Luisada-Opper A, Sorrell MF, Thomson AD, Baker H. Vitamin deficits in severe alcoholic fatty liver of man calculated from multiple reference units. Exp Mol Pathol. 1971;15(2):191-197.

67. Hoyumpa AM Jr. Mechanisms of thiamin deficiency in chronic alcoholism. Am J Clin Nutr. 1980;33(12):2750-2761.

68. Leevy CM, Baker H, Tenhove W, Frank O, Cherrick GR. B-complex vitamins in liver disease of the alcoholic. Am JClin Nutr. 1965;16(4):339-346.

69. Tomasulo PA, Kater RM, Iber FL. Impairment of thiamine absorption in alcoholism. Am J Clin Nutr. 1968;21(11):1341-1344.

70. Koike H, Mori K, Misu K, et al. Painful alcoholic polyneuropathy with predominant small-fiber loss and normal thiamine status. Neurology. 2001;56(12):1727-1732.

71. Koike H, Iijima M, Sugiura M, et al. Alcoholic neuropathy is clinicopathologically distinct from thiamine-deficiency neuropathy. Ann Neurol. 2003;54(1):19-29.

72. Chen X, Levine JD. Mechanically-evoked C-fiber activity in painful alcohol and AIDS therapy neuropathy in the rat. Mol Pain. 2007;3:5.

73. Chopra K, Tiwari V. Alcoholic neuropathy: possible mechanisms and future treatment possibilities. Br J Clin Pharmacol. 2012;73(3):348-362.

74. Narita M, Miyoshi K, Suzuki T. Involvement of microglia in the ethanol-induced neuropathic pain-like state in the rat. Neurosci Lett. 2007;414(1):21-25.

75. Miyoshi K, Narita M, Takatsu M, Suzuki T. mGlu5 receptor and protein kinase $\mathrm{C}$ implicated in the development and induction of neuropathic pain following chronic ethanol consumption. Eur J Pharmacol. 2007;562(3):208-211.

76. McDonough KH. Antioxidant nutrients and alcohol. Toxicology. 2003;189(1-2):89-97.

77. Dina OA, Barletta J, Chen X, et al. Key role for the epsilon isoform of protein kinase $\mathrm{C}$ in painful alcoholic neuropathy in the rat. JNeurosci. 2000;20(22):8614-8619.

78. Dina OA, Gear RW, Messing RO, Levine JD. Severity of alcoholinduced painful peripheral neuropathy in female rats: role of estrogen and protein kinase (A and CE). Neuroscience. 2007;145(1):350-356.

79. Jung ME, Gatch MB, Simpkins JW. Estrogen neuroprotection against the neurotoxic effects of ethanol withdrawal: potential mechanisms. Exp Biol Med (Maywood). 2005;230(1):8-22.

80. Chen CH, Ferreira JC, Gross ER, Mochly-Rosen D. Targeting aldehyde dehydrogenase 2: new therapeutic opportunities. Physiol Rev. 2014;94(1):1-34.

81. Röyttä M, Horwitz SB, Raine CS. Taxol-induced neuropathy: shortterm effects of local injection. J Neurocytol. 1984;13(5):685-701.

82. Röyttä M, Raine CS. Taxol-induced neuropathy: chronic effects of local injection. J Neurocytol. 1986;15(4):483-496.

83. Vuorinen V, Roytta M, Raine CS. The acute effects of taxol upon regenerating axons after nerve crush. Acta Neuropathol. 1988;76(1):26-34.

84. Vuorinen V, Roytta M, Raine CS. The acute response of Schwann cells to taxol after nerve crush. Acta Neuropathol. 1988;76(1):17-25.

85. Polomano RC, Mannes AJ, Clark US, Bennett GJ. A painful peripheral neuropathy in the rat produced by the chemotherapeutic drug, paclitaxel. Pain. 2001;94(3):293-304.

86. Lipton RB, Apfel SC, Dutcher JP, et al. Taxol produces a predominantly sensory neuropathy. Neurology. 1989;39(3):368-373.

87. Xiao WH, Bennett GJ. Chemotherapy-evoked neuropathic pain: abnormal spontaneous discharge in A-fiber and C-fiber primary afferent neurons and its suppression by acetyl-L-carnitine. Pain. 2008;135(3):262-270.

88. Cata JP, Weng HR, Burton AW, Villareal H, Giralt S, Dougherty PM. Quantitative sensory findings in patients with bortezomib-induced pain. J Pain. 2007;8(4):296-306.

89. Flatters SJ, Bennett GJ. Studies of peripheral sensory nerves in paclitaxel-induced painful peripheral neuropathy: evidence for mitochondrial dysfunction. Pain. 2006;122(3):245-257.

90. Postma TJ, Vermorken JB, Liefting AJ, Pinedo HM, Heimans JJ. Paclitaxel-induced neuropathy. Ann Oncol. 1995;6(5):489-494. 
91. Kus T, Aktas G, Kalender ME, et al. Taxane-induced peripheral sensorial neuropathy in cancer patients is associated with duration of diabetes mellitus: a single-center retrospective study. Support Care Cancer. 2016;24(3):1175-1179.

92. Smith EM, Pang H, Cirrincione C, et al. Effect of duloxetine on pain, function, and quality of life among patients with chemotherapyinduced painful peripheral neuropathy: a randomized clinical trial. JAMA. 2013;309(13):1359-1367.

93. Gaist D, Jeppesen U, Andersen M, Rodriguez LA, Hallas J, Sindrup SH. Statins and risk of polyneuropathy: a case-control study. Neurology. 2002;58(9):1333-1337.

94. LoYL, Leoh TH, Loh LM, Tan CE. Statin therapy and small fibre neuropathy: a serial electrophysiological study. J Neurol Sci. 2003;208(1-2): $105-108$.

95. Bhalla S, Singh N, Jaggi AS. Statins: do they aggravate or ameliorate neuropathic pain? J Pain. 2014;15(11):1069-1080.

96. Pathak NN, Balaganur V, Lingaraju MC, et al. Atorvastatin attenuates neuropathic pain in rat neuropathy model by down-regulating oxidative damage at peripheral, spinal and supraspinal levels. Neurochem Int. 2014;68:1-9.

97. Hernandez-Ojeda J, Roman-Pintos LM, Rodriguez-Carrizalez AD, et al. Effect of rosuvastatin on diabetic polyneuropathy: a randomized, double-blind, placebo-controlled Phase IIA study. Diabetes Metab Syndr Obes. 2014;7:401-407.

98. Finnerup NB, Attal N, Haroutounian S, et al. Pharmacotherapy for neuropathic pain in adults: a systematic review and meta-analysis. Lancet Neurol. 2015;14(2):162-173.

99. Boyle J, Eriksson ME, Gribble L, et al. Randomized, placebo-controlled comparison of amitriptyline, duloxetine, and pregabalin in patients with chronic diabetic peripheral neuropathic pain: impact on pain polysomnographic sleep, daytime functioning, and quality of life. Diabetes Care. 2012;35(12):2451-2458.

100. Jose VM, Bhansali A, Hota D, Pandhi P. Randomized double-blind study comparing the efficacy and safety of lamotrigine and amitriptyline in painful diabetic neuropathy. Diabet Med.2007;24(4):377-383.

101. Max MB, Culnane M, Schafer SC, et al. Amitriptyline relieves diabetic neuropathy pain in patients with normal or depressed mood. Neurology. 1987;37(4):589-596.

102. Sindrup SH, Ejlertsen B, Frøland A, Sindrup EH, Brøsen K, Gram LF. Imipramine treatment in diabetic neuropathy: relief of subjective symptoms without changes in peripheral and autonomic nerve function. Eur J Clin Pharmacol. 1989;37(2):151-153.

103. Sindrup SH, Otto M, Finnerup NB, Jensen TS. Antidepressants in the treatment of neuropathic pain. Basic Clin Pharmacol Toxicol. 2005;96(6):399-409.

104. Moore RA, Derry S, Aldington D, Cole P, Wiffen PJ. Amitriptyline for neuropathic pain and fibromyalgia in adults. Cochrane Database Syst Rev. 2015;7:CD008242.

105. Derry S, Wiffen PJ, Aldington D, Moore RA. Nortriptyline for neuropathic pain in adults. Cochrane Database Syst Rev. 2015;1:CD011209.

106. Basbaum AI, Bautista DM, Scherrer G, Julius D. Cellular and molecular mechanisms of pain. Cell. 2009;139(2):267-284.

107. Julius D, Basbaum AI. Molecular mechanisms of nociception. Nature. 2001;413(6852):203-210.

108. Basbaum AI. Spinal mechanisms of acute and persistent pain. Reg Anesth Pain Med. 1999;24(1):59-67.

109. Iyengar S, Webster AA, Hemrick-Luecke SK, Xu JY, Simmons RM. Efficacy of duloxetine, a potent and balanced serotonin-norepinephrine reuptake inhibitor in persistent pain models in rats. $J$ Pharmacol Exp Ther. 2004;311(2):576-584.

110. Arnold LM, Lu Y, Crofford LJ, et al. A double-blind, multicenter trial comparing duloxetine with placebo in the treatment of fibromyalgia patients with or without major depressive disorder. Arthritis Rheum. 2004;50(9):2974-2984.

111. Arnold LM, Pritchett YL, D'Souza DN, Kajdasz DK, Iyengar S, Wernicke JF. Duloxetine for the treatment of fibromyalgia in women: pooled results from two randomized, placebo-controlled clinical trials. J Womens Health (Larchmt). 2007;16(8):1145-1156.
112. Fishbain DA, Detke MJ, Wernicke J, Chappell AS, Kajdasz DK. The relationship between antidepressant and analgesic responses: findings from six placebo-controlled trials assessing the efficacy of duloxetine in patients with major depressive disorder. Curr Med Res Opin. 2008;24(11):3105-3115.

113. Gendreau RM, Thorn MD, Gendreau JF, et al. Efficacy of milnacipran in patients with fibromyalgia. $J$ Rheumatol. 2005;32(10): 1975-1985.

114. Marks DM, Shah MJ, Patkar AA, Masand PS, Park GY, Pae CU. Serotonin-norepinephrine reuptake inhibitors for pain control: premise and promise. Curr Neuropharmacol. 2009;7(4):331-336.

115. Rowbotham MC, Goli V, Kunz NR, Lei D. Venlafaxine extended release in the treatment of painful diabetic neuropathy: a double-blind, placebo-controlled study. Pain. 2004;110(3):697-706.

116. Neil MJ. Clonidine: clinical pharmacology and therapeutic use in pain management. Curr Clin Pharmacol. 2011;6(4):280-287.

117. Lunn MP, Hughes RA, Wiffen PJ. Duloxetine for treating painful neuropathy, chronic pain or fibromyalgia. Cochrane Database Syst Rev. 2014;(1):CD007115.

118. Matthews EA, Dickenson AH. Effects of spinally delivered N- and P-type voltage-dependent calcium channel antagonists on dorsal horn neuronal responses in a rat model of neuropathy. Pain. 2001;92(1-2): 235-246.

119. Kato A, Ohkubo T, Kitamura K. Algogen-specific pain processing in mouse spinal cord: differential involvement of voltage-dependent $\mathrm{Ca}(2+)$ channels in synaptic transmission. $\mathrm{Br} J$ Pharmacol. 2002;135(5):1336-1342.

120. Woolf CJ, Salter MW. Neuronal plasticity: increasing the gain in pain. Science. 2000;288(5472):1765-1769.

121. Rumore MM, Aron SM, Hiross EJ. A review of mechanism of action of aspirin and its potential as an immunomodulating agent. Med Hypotheses. 1987;22(4):387-400.

122. Bauer CS, Nieto-Rostro M, Rahman W, et al. The increased trafficking of the calcium channel subunit $\alpha_{2} \delta-1$ to presynaptic terminals in neuropathic pain is inhibited by the $\alpha_{2} \delta$ ligand pregabalin. J Neurosci. 2009;29(13):4076-4088.

123. Luo ZD, Chaplan SR, Higuera ES, et al. Upregulation of dorsal root ganglion $\alpha_{2} \delta$ calcium channel subunit and its correlation with allodynia in spinal nerve-injured rats. $J$ Neurosci. 2001;21(6):1868-1875.

124. Li CY, Song YH, Higuera ES, Luo ZD. Spinal dorsal horn calcium channel $\alpha_{2} \delta-1$ subunit upregulation contributes to peripheral nerve injury-induced tactile allodynia. $J$ Neurosci. 2004;24(39): 8494-8499.

125. Boroujerdi A, Kim HK, Lyu YS, et al. Injury discharges regulate calcium channel alpha-2-delta-1 subunit upregulation in the dorsal horn that contributes to initiation of neuropathic pain. Pain. 2008; 139(2):358-366.

126. Marais E, Klugbauer N, Hofmann F. Calcium channel $\alpha_{2} \delta$ subunitsstructure and gabapentin binding. Mol Pharmacol. 2001;59(5): $1243-1248$

127. Moore RA, Straube S, Wiffen PJ, Derry S, McQuay HJ. Pregabalin for acute and chronic pain in adults. Cochrane Database Syst Rev. 2009;(3):CD007076.

128. Donvito G, Wilkerson JL, Damaj MI, Lichtman AH. Palmitoylethanolamide reverses paclitaxel-induced allodynia in mice. J Pharmacol Exp Ther. 2016;359(2):310-318.

129. Moore RA, Wiffen PJ, Derry S, Toelle T, Rice AS. Gabapentin for chronic neuropathic pain and fibromyalgia in adults. Cochrane Database Syst Rev. 2014;(4):CD007938.

130. McGivern JG. Ziconotide: a review of its pharmacology and use in the treatment of pain. Neuropsychiat Dis Treat. 2007;3(1):69-85.

131. Pope JE, Deer TR, Bruel BM, Falowski S. Clinical uses of intrathecal therapy and its placement in the pain care algorithm. Pain Pract. Epub 2016 Feb 23.

132. McDowell GC 2nd, Pope JE. Intrathecal ziconotide: dosing and administration strategies in patients with refractory chronic pain. Neuromodulation. 2016;19(5):522-532. 
133. Sanford M. Intrathecal ziconotide: a review of its use in patients with chronic pain refractory to other systemic or intrathecal analgesics. CNS Drugs. 2013;27(11):989-1002.

134. Hayek SM, Hanes MC. Intrathecal therapy for chronic pain: current trends and future needs. Curr Pain Headache Rep. 2014; 18(1):388.

135. Laursen L. Palliative care: the other opioid issue. Nature. 2016; 535(7611):S16-S17.

136. Schepers RJ, Mahoney JL, Shippenberg TS. Inflammation-induced changes in rostral ventromedial medulla mu and kappa opioid receptor mediated antinociception. Pain. 2008;136(3):320-330.

137. Hurley RW, Hammond DL. The analgesic effects of supraspinal $\mu$ and $\delta$ opioid receptor agonists are potentiated during persistent inflammation. J Neurosci. 2000;20(3):1249-1259.

138. Fields H. State-dependent opioid control of pain. Nat Rev Neurosci. 2004;5(7):565-575.

139. Stein C, Schafer M, Machelska H. Attacking pain at its source: new perspectives on opioids. Nat Med. 2003;9(8):1003-1008.

140. Vanderah TW. Delta and kappa opioid receptors as suitable drug targets for pain. Clin J Pain. 2010;26(Suppl 10):S10-S15.

141. Ma F, Xie H, Dong ZQ, Wang YQ, Wu GC. Expression of ORL1 mRNA in some brain nuclei in neuropathic pain rats. Brain Res. 2005;1043(1-2):214-217.

142. Chen Y, Sommer C. Nociceptin and its receptor in rat dorsal root ganglion neurons in neuropathic and inflammatory pain models: implications on pain processing. J Peripher Nerv Syst. 2006;11(3): 232-240.

143. Kabli N, Cahill CM. Anti-allodynic effects of peripheral delta opioid receptors in neuropathic pain. Pain. 2007;127(1-2):84-93.

144. Briscini L, Corradini L, Ongini E, Bertorelli R. Up-regulation of ORL-1 receptors in spinal tissue of allodynic rats after sciatic nerve injury. Eur J Pharmacol. 2002;447(1):59-65.

145. Sun RQ, Wang Y, Zhao CS, Chang JK, Han JS. Changes in brain content of nociceptin/orphanin FQ and endomorphin 2 in a rat model of neuropathic pain. Neurosci Lett. 2001;311(1):13-16.

146. Nadal X, Banos JE, Kieffer BL, Maldonado R. Neuropathic pain is enhanced in $\delta$-opioid receptor knockout mice. Eur J Neurosci. 2006;23(3):830-834

147. Aita M, Byers MR, Chavkin C, Xu M. Trigeminal injury causes kappa opioid-dependent allodynic, glial and immune cell responses in mice. Mol Pain. 2010;6:8.

148. Obara I, Mika J, Schafer MK, Przewlocka B. Antagonists of the $\kappa$-opioid receptor enhance allodynia in rats and mice after sciatic nerve ligation. Br J Pharmacol. 2003;140(3):538-546.

149. Xu M, Petraschka M, McLaughlin JP, et al. Neuropathic pain activates the endogenous $\kappa$ opioid system in mouse spinal cord and induces opioid receptor tolerance. J Neurosci. 2004;24(19):4576-4584.

150. Mika J, Przewlocki R, Przewlocka B. The role of $\delta$-opioid receptor subtypes in neuropathic pain. Eur J Pharmacol. 2001;415(1): $31-37$.
151. Petrillo P, Angelici O, Bingham S, et al. Evidence for a selective role of the $\delta$-opioid agonist [8R-(4bS*,8a $\alpha, 8 \mathrm{a} \beta, 12 \mathrm{~b} \beta)] 7,10$-Dimethyl1-methoxy-11-(2-methylpropyl)oxycarbonyl 5,6,7,8,12,12b-hexahydro-(9H)-4,8-methanobenzofuro[3,2-e]pyrrolo[2,3-g]isoquinoline hydrochloride (SB-235863) in blocking hyperalgesia associated with inflammatory and neuropathic pain responses. J Pharmacol Exp Ther. 2003;307(3):1079-1089.

152. Abraham KE, Brewer KL, McGinty JF. Opioid peptide messenger RNA expression is increased at spinal and supraspinal levels following excitotoxic spinal cord injury. Neuroscience. 2000;99(1):189-197.

153. Akbar S, Subhan F, Karim N, et al. 6-Methoxyflavanone attenuates mechanical allodynia and vulvodynia in the streptozotocin-induced diabetic neuropathic pain. Biomed Pharmacother. 2016;84:962-971.

154. Mogil JS, Grisel JE, Zhangs G, Belknap JK, Grandy DK. Functional antagonism of $\mu$-, $\delta$ - and $\kappa$-opioid antinociception by orphanin FQ. Neurosci Lett. 1996;214(2-3):131-134.

155. Mabuchi T, Matsumura S, Okuda-Ashitaka E, et al. Attenuation of neuropathic pain by the nociceptin/orphanin FQ antagonist JTC-801 is mediated by inhibition of nitric oxide production. Eur J Neurosci. 2003;17(7):1384-1392.

156. Scoto GM, Arico G, Iemolo A, Ronsisvalle S, Parenti C. Involvement of the nociceptin/orphanin FQ-NOP receptor system in the ventrolateral periaqueductal gray following mechanical allodynia in chronic pain. Life Sci. 2009;85(5-6):206-210.

157. Schiene K, Tzschentke TM, Schröder W, Christoph T. Mechanical hyperalgesia in rats with diabetic polyneuropathy is selectively inhibited by local peripheral nociceptin/orphanin FQ receptor and $\mu$-opioid receptor agonism. Eur J Pharmacol. 2015;754:61-65.

158. Ding H, Hayashida K, Suto T, et al. Supraspinal actions of nociceptin/ orphanin FQ, morphine and substance $P$ in regulating pain and itch in non-human primates. Br J Pharmacol. 2015;172(13):3302-3312.

159. Ko MC, Naughton NN. Antinociceptive effects of nociceptin/orphanin FQ administered intrathecally in monkeys. J Pain. 2009;10(5):509-516.

160. Kalso E. Sodium channel blockers in neuropathic pain. Curr Pharm Des. 2005;11(23):3005-3011.

161. Bhattacharya A, Wickenden AD, Chaplan SR. Sodium channel blockers for the treatment of neuropathic pain. Neurotherapeutics. 2009;6(4):663-678.

162. Dray A. Neuropathic pain: emerging treatments. $\mathrm{Br} J$ Anaesth. 2008;101(1):48-58.

163. Brochu RM, Dick IE, Tarpley JW, et al. Block of peripheral nerve sodium channels selectively inhibits features of neuropathic pain in rats. Mol Pharmacol. 2006;69(3):823-832.

164. Eisenstein M. Neuropathy: a name for their pain. Nature. 2016; 535(7611):S10-S11.

165. Le Pichon CE, Chesler AT. The functional and anatomical dissection of somatosensory subpopulations using mouse genetics. Front Neuroanat. 2014;8:21.

166. Benarroch EE. Ion channels in nociceptors: recent developments. Neurology. 2015;84(11):1153-1164.
Journal of Pain Research

\section{Publish your work in this journal}

The Journal of Pain Research is an international, peer reviewed, open access, online journal that welcomes laboratory and clinical findings in the fields of pain research and the prevention and management of pain. Original research, reviews, symposium reports, hypothesis formation and commentaries are all considered for publication.

\section{Dovepress}

The manuscript management system is completely online and includes a very quick and fair peer-review system, which is all easy to use. Visit http://www.dovepress.com/testimonials.php to read real quotes from published authors. 